\title{
Physiological responses to folivory and phytopathogens in a riparian tree, Brabejum stellatifolium, native to the fynbos biome of South Africa
}

\author{
Malebajoa A. Maoela ${ }^{1}$ (D) | Karen J. Esler ${ }^{1,2,3}$ | Francois Roets ${ }^{1,4}$ | Shayne M. Jacobs ${ }^{1,3}$
}

${ }^{1}$ Department of Conservation Ecology and Entomology, Stellenbosch University,

Matieland, South Africa

${ }^{2}$ DST/NRF Centre of Excellence for Invasion Biology, Stellenbosch University, Matieland, South Africa

${ }^{3}$ Water Institute, Stellenbosch University, Stellenbosch, South Africa

${ }^{4}$ DST/NRF Centre of Excellence in Tree Health Biotechnology (CTHB), Forestry and Agricultural Biotechnology Institute (FABI), University of Pretoria, Pretoria, South Africa

Correspondence

Malebajoa A. Maoela

Email: malebajoam@gmail.com

Funding information

DST/NRF Centre of Excellence in Tree

Health Biotechnology

\begin{abstract}
The canopies of many tree species sustain a large diversity of folivorous arthropods and phytopathogenic fungi. These organisms are thought to influence overall tree and stand productivity. Leaf diseases caused by Phyllosticta owaniana and Periconiella velutina, phytopathogenic fungi commonly found on the native riparian tree Brabejum stellatifolium (wild almond), like any other leaf disease, can potentially reduce a plant's photosynthetic efficiency. In addition to these two phytopathogens, the weevils Setapion provinciale and Setapion quantillum are abundant in wild almond canopies. Despite their pervasive occurrence, the impacts of these phytopathogens and arthropods on host tree leaf physiology have not been examined. The gas exchange response of wild almond leaves to phytopathogens and folivore damage was assessed. Leaf nitrogen, phosphorus and water content were also determined. Declines in photosynthetic rates and other physiological parameters were associated with increasing damage severity by weevils and phytopathogens in leaves of B. stellatifolium. Nitrogen and phosphorus contents were negatively associated with disease severity. Water and phosphorus contents were also negatively correlated with increased weevil damage, while nitrogen content was positively correlated with it. The observed responses of $B$. stellatifolium metabolic functioning to fungal pathogen and folivory indicate a possibility of suppressed wild populations of wild almond.

\section{Résumé}

La canopée de nombreuses espèces d'arbres héberge une grande diversité d'arthropodes folivores et de champignons phyto-pathogènes. L'on pense que ces organismes influencent la productivité générale des arbres et des jeunes plants. La maladie des feuilles causée par Phyllosticta owaniana et Periconiella velutina, des champignons phytopathogènes que l'on trouve fréquemment sur l'arbre riverain indigène Brabejum stellatifolium (amandier sauvage) peut, comme toute autre maladie des feuilles, réduire l'efficacité de la photosynthèse d'une plante. En plus de ces deux phytopathogènes, les charançons Setapion provinciale et Setapion quantillum sont abondants dans la canopée des amandiers sauvages. Malgré cette présence envahissante, les impacts de ces phytopathogènes et des arthropodes sur la physiologie des feuilles des arbres hôtes n'ont pas encore été étudiés. L'échange de gaz des feuilles d'amandiers sauvages qui répond aux dommages causés par les phytopathogènes et aux folivores a été étudié. Le contenu des feuilles en azote, en phosphore et en eau a
\end{abstract}


aussi été déterminé. Les diminutions du rythme de la photosynthèse et d'autres paramètres physiologiques ont été associés à la gravité croissante des dommages dus aux charançons et aux phytopathogènes dans les feuilles de B. stellatifolium. Les contenus en azote et en phosphore étaient négativement liés à la gravité des maladies. Les contenus en eau et en phosphore étaient aussi négativement liés à la croissance des dommages causés par les charançons, alors que les contenus en azote étaient positivement liés à cet élément. Les réponses observées dans le fonctionnement métabolique de $B$. stellatifolium suite aux atteintes des pathogènes fongiques et des folivores indiquent qu'il serait possible voir disparaitre certaines populations sauvages d'amandiers sauvages.

\section{KEYWORDS}

gas exchange, nitrogen, phosphorus content, water

\section{1 | INTRODUCTION}

Folivorous arthropods and phytopathogens cause damage to photosynthetic tissue, thereby affecting plant growth and, ultimately, the primary production of plant communities (Aldea et al., 2006; Nabity, Zavala, \& Delucia, 2009; Sinclair \& Hughes, 2010; Yang et al., 2007). Insect folivory is known to reduce net primary production in forests, grasslands and global agricultural output by an average of 15, 24 and $14 \%$, respectively. This destruction can exceed $70 \%$ during outbreaks (Carmona, Lajeunesse, \& Johnson, 2011; Schowalter, 2012). A number of researchers have explored how phytopathogens and folivores reduce net photosynthesis either through direct observation and measurement (Bechtold, Karpinski, \& Mullineaux, 2005; King \& Caylor, 2010; Maoela, Jacobs, Roets, \& Esler, 2016; Thomson, Cunningham, Ball, \& Nicotra, 2003; Zvereva, Lanta, \& Kozlov, 2010) or through modelling (e.g., Lopes \& Berger, 2001). The results from these studies show that levels of impact resulting from activities of insect folivores and phytopathogens on photosynthesis vary and largely depend on the type of feeding damage (e.g., piercing or chewing). This impact also depends on the type of fungal disease (e.g. chlorotic or necrotic leaf lesions) or the mode of defence deployed by the host plant involved (Aldea et al., 2005; Nabity et al., 2009; Tatagiba, Damatta, \& Rodrigues, 2015; Tatagiba, Rodrigues, Filippi, Silva, \& Silva, 2014). Furthermore, a review by Nabity et al. (2009) also showed that the impact of folivory on photosynthetic rate is generally negative regardless of feeding mode.

The direct loss of foliage due to folivore activities generally leads to a reduction in photosynthetic capacity (Nabity et al., 2009). A growing body of evidence suggests that the underlying mechanisms leading to a reduction in leaf photosynthetic capacity are complex. These mechanisms range from fluid disruptions mostly through nutrient transport (Sack \& Holbrook, 2006), induced reductions in metabolic processes (e.g., Zvereva et al., 2010) to triggering defencerelated responses (Kessler \& Baldwin, 2002). For instance, in the leaves of Quercus velutina Lam. and Cercis canadensis L., the deleterious action of folivores and phytopathogens affects electron transport in the chloroplasts of the remaining tissues, thereby reducing photosynthetic rate (Aldea et al., 2005). This is the result of changes in the primary photosynthetic reactions (as reported by Velikova et al., 2010) which can be manifested in various forms. One way is through reduced carbon assimilation rates and photosystem II quantum operating efficiency in damaged leaves (Zvereva et al., 2010) because of triggered production of defence compounds to dissuade folivorous insects and fungal pathogen attacks (Bown, Hall, \& Macgregor, 2002; León, Rojo, \& Sanchez-Serrano, 2001; Small, Flett, Marasas, McLeod, \& Viljoen, 2012). Another is through the emissions of volatile organic compounds which can affect defence mechanisms of plants (Dicke \& Hilker, 2003). Lastly, through internal recycling of carbon and nitrogen, which can be diverted away from primary metabolism like production of photosynthetic enzymes to induce production of defence compounds (Agrawal, Karban, \& Colfer, 2000; Aldea et al., 2006). The diversion of carbon and nitrogen away from primary metabolism may be exacerbated when it is necessary for a plant to produce defence compounds against damage caused by folivorous insects and/or phytopathogens simultaneously (Mithöfer $\&$ Boland, 2012). This may increase the rate of leaf abscission (Manter \& Kavanagh, 2003) instead of offering cross-protection (Aldea et al., 2006). Plant nutritional quality and plant water relations may be impacted negatively through a reduction in photosynthesis as a result of folivory or polypathogen activities (Robert, Bancal, \& Lannou, 2002; Santos, Alves-Silva, Cornelissen, \& Fernandes, 2013; Santos, Santos, et al., 2013; Snoeijers, Pérez-Garcia, Joosten, \& Wit, 2000).

Nitrogen is essential for growth, survival and reproduction of folivores (Ayres, Wilkens, Ruel, Lombardero, \& Vallery, 2000; Bentz \& Townsend, 2001), and also for growth and development of phytopathogens on or within plants (Franzluebbers \& Hill, 2005; Larkin, Hunt, \& Ramsey, 2012). On entering a plant, the amount of nitrogen (N) available to a fungal pathogen will depend on the tissues being colonized and nitrogen content of that invaded tissue (Walters \& 
Bingham, 2007). Mode of nutrition may also affect available nitrogen, with hemibiotrophic phytopathogens having access to a wider range of $\mathrm{N}$ sources than biotrophic phytopathogens, which are limited by the amount of available $\mathrm{N}$ in extrahaustorial matrix of apoplasts (Olufemi, Georgina, Sunday, Oyeboade, \& Taiwo, 2002).

Available data show a direct relationship between increase in fungal disease and insect folivory severity on the one hand and increase in leaf $\mathrm{N}$ content on the other (Bancal, Robert, \& Ney, 2007; Carvalho et al., 2014; Robert, Bancal, Ney, \& Lannou, 2005). The effects of phosphorus $(P)$ on the impact of fungal diseases and folivory are not well understood, as results of various studies are contradictory. For instance, Sweeney, Granade, Eversmeyer, and Whitney (2000) showed that $P$ had a moderately suppressive effect on wheat leaf rust. Djassinra, Elhartiti, Mammad, and Ounine (2015) found that elevated P content increased the severity of Xanthomonas fragariae disease on strawberry plants although the increase in disease severity was relatively low when compared to increasing $N$ content. However, general trends relating to fungal pathogen damage and insect folivory on foliar nutrients, and their effect on plant functioning is equivocal as there are few systematic studies which compare these two damage types (e.g., Awmack \& Leather, 2002; Ayres et al., 2000; Huberty \& Denno, 2006).

We investigated the physiological parameters and leaf nutrients in wild almond leaves with varying levels of fungal pathogen and folivore damage in this study. This investigation was to (i) ascertain why some native plants, for example Brabejum stellatifolium and $M$. angustifolia in restored riparian zones recover slowly after removal of invasive alien plants such as A. mearnsii (as shown in Maoela et al., 2016), and (ii) provide insights into how the employed plant defence mechanisms are likely to affect the metabolic costs of affected hosts, as well as the activities of folivores and fungal pathogens. The following questions on the interaction between phytopathogens, folivorous insects and their host B. stellatifolium L. were addressed: (i) What are the impacts of the phytopathogens Phyllosticta owaniana (G. Winter) and Periconiella velutina (G. Winter) and the weevils Setapion provinciale (Balfour-Browne) and Setapion quantillum (BalfourBrowne) on gas exchange in leaves? (ii) How do gas exchange parameters, nutrients and water contents relate to damage severity?

\section{2 | MATERIALS AND METHODS}

\subsection{Study area}

We conducted our study along the Eerste River at Jonkershoek nature

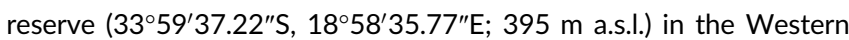
Province of South Africa. The natural vegetation of the Jonkershoek area is mainly mountain fynbos (Buys, van der Walt, \& Boucher, 1991). The study area lies near the town of Stellenbosch in the south-western Cape and is topographically defined and enclosed by mountain ranges. The predominant surrounding land use of the nature reserve is mostly a combination of natural areas and agriculture (vineyards). Its climate is fairly typical of the south-western Cape commonly described as "Etesian of the Mediterranean type" (Werger, Kruger, \& Taylor, 1972).
Summers are warm to very hot and strong south-easterly winds prevail, creating a serious fire hazard.

\section{2 | Study tree species}

Brabejum stellatifolium (L.) (Proteaceae) is one of the most predominant tree species endemic to Fynbos biome of the Western Cape Province, South Africa (Crous, Jacobs, \& Esler, 2011). It prefers moist areas, and commonly occurs in riparian areas and can tolerate a variety of soils and habitats (Crous et al., 2011; Swift, Jacobs, \& Esler, 2008). This evergreen tree resembles Australian Proteaceae more closely than it does to South African members of the family because of its morphological characters like flower pairs and stylar pollen presentation (Hoot \& Douglas, 1998).

\section{3 | Phytopathogens and weevils}

Assessment of leaf damage (see Maoela et al., 2016) confirmed that wild almond leaves are commonly infected by Phyllosticta spp. causing leaf spots and Periconiella spp. (black sooty mould) throughout riparian zones in the Western Cape Province. Phyllosticta and Periconiella are large genera of ascomycete fungi, which together with numerous other species of fungi, cause diseases on a variety of host plants (Stone, Polishook, \& White, 2004). Phyllosticta spp. occur in most temperate and Mediterranean habitats, and the diseases they cause are largely characterized by chlorotic to necrotic localized lesions (Martínez-Minaya, Conesa, LopezQuilez, \& Vicent, 2015). Periconiella spp. (black sooty mould) is described as nonparasitic, saprophytic and superficial on plants (Jouraeva et al., 2006). They are normally found on abaxial leaf surfaces, giving the leaf a black colour. The specific Phyllosticta and Periconiella species that infect wild almond in Western Cape riparian sites were identified as $P$. owaniana and P. velutina (Arzanlou et al., 2007; Swart, Crous, Denman, \& Palm, 1998). Lesions of $P$. owaniana typically are between 2 and $10 \mathrm{~mm}$ in diameter and are angular to nearly round. $P$. velutina produces darkbrown spores on the adaxial surfaces of the lesions and produces conidia on dark reddish brown stromata.

Apart from the two mentioned phytopathogens, there are two species of weevils most abundant in the South-Western Cape (S. provinciale and S. quantillum) that are host specific to B. stellatifolium (Procheş, 2007). They are members of an African endemic group of Apionidae called Tanaonimi (Procheş, 2007). S. provinciale appears only in spring (August to mid-October), whereas S. quantillum is likely to be seen throughout the year (Procheş, 2007). Despite occurring in large numbers, into the hundreds of millions (see Procheş, 2007), no study has been undertaken quantifying leaf physiological responses to their damage. Damage by each weevil was not considered separately as both species create numerous very small openings in the cuticle of the leaf.

\subsection{Measurements of leaf physiological variables}

Before starting the measurements of leaf physiological parameters, visual assessment of the presence of folivory damage caused by 
P. owaniana and P. velutina diseases was conducted on each of 10 trees (diameter at breast height between 10 and $28 \mathrm{~cm}$ ) in February 2010 in Eerste River at Jonkershoek. Selected individuals had similar heights and stem diameters for each species, respectively, across all sites (to minimize possible difference in susceptibility due to plant age), and all were within $5 \mathrm{~m}$ of the water's edge (to minimize possible differences in susceptibility due to water stress) (Crous et al., 2011). From each of the 10 selected trees, 12 fully expanded leaves were randomly chosen to study their physiology. Leaves damaged by both fungi and insects were not considered in this study. Black mould-infected leaves were also separated from leaf spot infected leaves. Each of the selected leaves was visually analysed for damage and disease severity (intact $=0 \%$ [used as control leaves]; $1=>0 \%$ $20 \% ; 2=21 \%-40 \% ; 3=41 \%-60 \%$ and $4=61 \%-100 \%$ of leaf area damaged). This method was modified from García-Guzmán \& Dirzo (2001, 2004) and Eichhorn, Nilus, Compton, Hartley, and Burslem (2010). Damage severity was defined as the percentage of leaf area visibly infected by a fungal pathogen or area damaged by feeding activities of arthropods.

After measuring photosynthesis, all experimental leaves (30 damaged by weevils, 39 by leaf spot fungus, and 31 black-mould infected) were removed from the trees (with their petioles intact) and immediately transported to the laboratory, where their outlines were traced on a transparency and photographed (Table S1). Images were then used to determine the percentage of leaf tissue consumed by weevils and infected by fungi using Digimizer image analysis software (v 4.2.2, MedCalc Software, Ostend, Belgium). Digimizer measurements were considered for data analyses and regrouped into five categories used in visual estimation of damage levels.

\subsubsection{Net photosynthesis measurements}

All experiments were conducted during midday in summer, when air temperatures were above $30^{\circ} \mathrm{C}$. Obtaining photosynthesis measurements under natural environmental conditions is important to determine the status of radiation-use efficiency (Bradford, Hicke, \& Lauenroth, 2005). A portable photosynthesis system, LCPro (ADC, Hoddesdon, UK), was used to collect photosynthetic measurements from individual leaves (matured and fully expanded), still attached to the tree. The chosen leaves were fully exposed to sunlight. On each individual tree, 10 damaged leaves were randomly selected, and paired with three comparable, but undamaged leaves which served as a control. Using the LCPro, two to four photosynthetic rate $\left(A_{\text {max }}\right)$, measurements per leaf were collected, and the values averaged to yield a single value for each leaf, for data analysis. Measurements were carried out from 12:00 to $14: 00 \mathrm{hr}$ when photosynthetic photon flux density levels are usually at their highest (Pellegrini et al., 2015) so that all B. stellatifolium leaves were light saturated. The stomatal conductance $\left(g_{s}\right)$, transpiration rate $(E)$ and leaf temperature $\left(T_{\text {leaf }}\right.$ in $\left.{ }^{\circ} \mathrm{C}\right)$ variables were measured concurrently with photosynthetic rate by appropriate sensors installed within the leaf chamber.

\subsection{2 | Leaf water content}

A separate set of 20 leaves per type of damage (apart from the ones used for photosynthesis measurements) were collected and weighed to determine fresh weight. They were then dried in an oven for $48 \mathrm{hr}$ at a temperature of $60^{\circ} \mathrm{C}$, to determine the dry weight (DW). Damage severity was determined as outlined above for leaves used in photosynthesis measurements.

\subsection{3 | Leaf nutrient content analysis}

Nutrient analyses were performed on dried leaf tissue samples that were used for leaf water content determination. These tests were performed by the Institute for Plant Production in Western Cape Department of Agriculture. Nitrogen concentrations were determined by following the semimicro Kjeldahl method using a Tecator Kjeltec Auto 1030 Analyser after saturating samples in concentrated sulphuric acid with a selenium catalyst. Phosphorus was measured using an Inductively Coupled Plasma Spectrometer (Sáez-Plaza, Michałowski, Navas, \& Asuero, 2013, and reference therein).

\section{5 | Data analyses}

A one-way analysis of variance (ANOVA) followed by a post hoc Tukey multiple comparison test was used to examine differences in leaf gas-exchange processes and nutrients (separately) between the control and various damage severity classes in mature leaves. Pearson's correlation was used to examine the relationships between increases in damage severity and increases in $A_{\max }, g_{s}, E, T_{\text {leaf }}$ and leaf nutrients for each damage type. Pearson's correlation coefficients were calculated to examine the strength of these relationships (Table S2). All statistical analyses were performed in STATISTICA version 11 (Statsoft, Corporation Tulsa, USA).

\section{RESULTS}

\subsection{Black mould (Periconiella velutina) - photosynthesis and gas exchange relationships}

There was significant negative correlation between the amount of leaf area covered by black mould and photosynthetic rate $\left(A_{\max }\right.$ : $r^{2}=.71$; Figure 1a). B. stellatifolium leaves with low damage levels had significantly lower mean photosynthesis values compared to undamaged leaves $\left(F_{[1,49]}=17.74, p<.001\right.$; Table 1). As damage increased, a significant decrease in $A_{\max }$ was observed for severely damaged areas (Table 1). Other physiological processes were also affected by black mould disease. A small increase in damaged leaf area resulted in large and significant reduction in stomatal conductance ( $g_{s}: r^{2}=.67$; Figure $1 \mathrm{~b}$ ), as indicated by decreasing mean values at increasing damage intervals $\left(F_{[1,} 49\right]=72.06, p<.001$; Table 1). Stomatal conductance has a close relationship with leaf transpiration as water exits the leaf through the stomata. In our study, transpiration and damage intensity (damaged leaf area) were 
FIGURE 1 Photosynthetic rate $\left(A_{\max }\right.$ : a), net stomatal conductance ( $\left.g_{s}: b\right)$, transpiration $(E: c)$ and leaf temperature $\left({ }^{\circ} \mathrm{C}\right)\left(T_{\text {leaf }}: d\right)$ in relation to percentage of leaves in the crowns of Brabejum stellatifolium trees infected by black mould. $r^{2}=$ Pearson's correlation coefficients. All the trends were nonlinear; polynomials provided the best fit
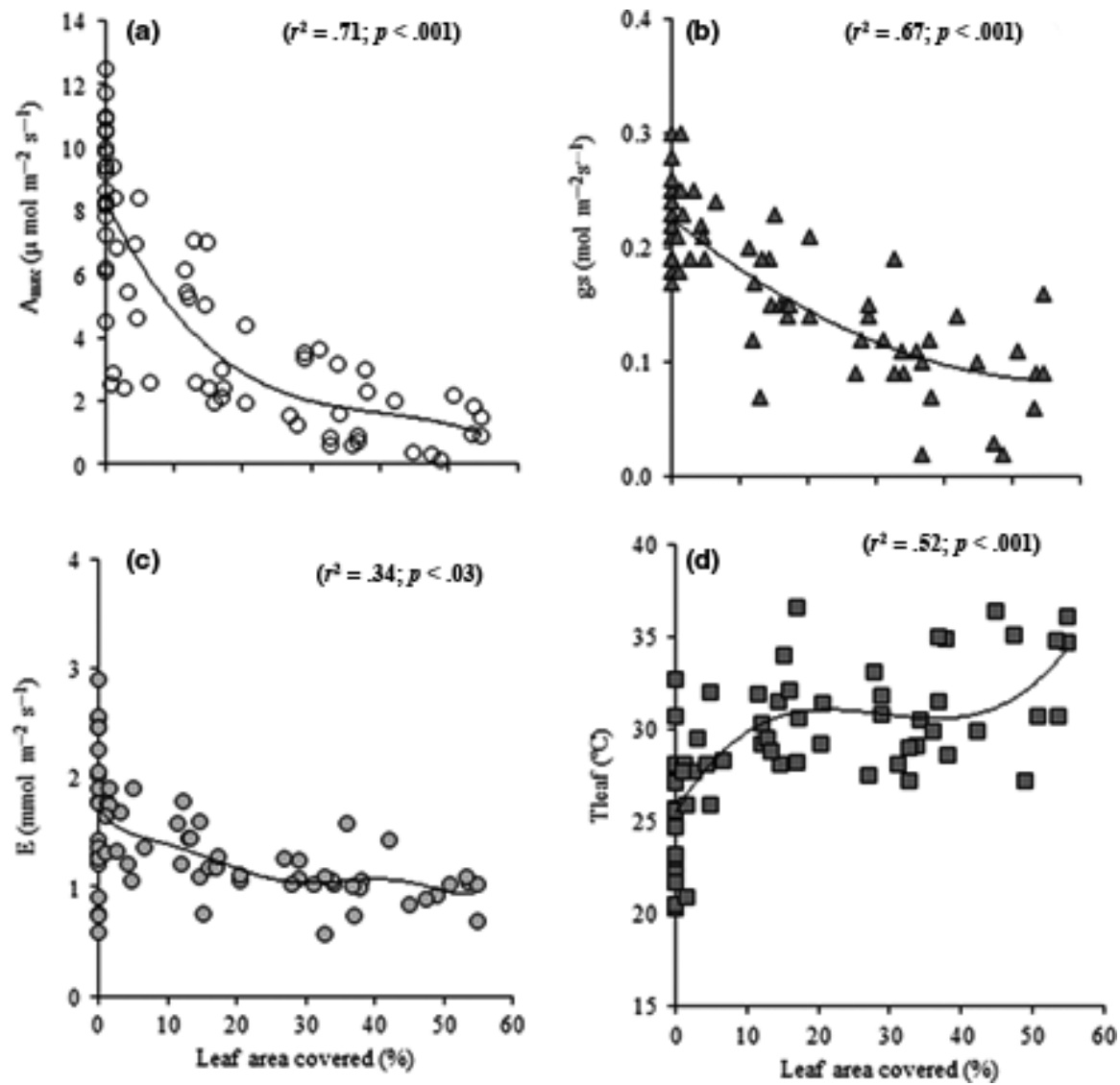

TABLE 1 Effects of black mould on mean photosynthetic rate $\left(A_{\max }\right)$, stomatal conductance $\left(g_{s}\right)$, leaf temperature $\left(T_{\text {leaf }}\right)$ and leaf transpiration (E) of $B$. stellatifolium leaves

\begin{tabular}{lllll} 
Damage category & $A_{\max }$ & $g_{\mathrm{s}}$ & $T_{\text {leaf }}$ & $E$ \\
\hline Control & $8.99 \pm 0.45^{\mathrm{a}}$ & $0.22 \pm 0.01^{\mathrm{a}}$ & $25.35 \pm 0.69^{\mathrm{a}}$ & $1.71 \pm 0.15^{\mathrm{a}}$ \\
\hline$>0 \%-20 \%$ & $4.78 \pm 0.48^{\mathrm{b}}$ & $0.23 \pm 0.01^{\mathrm{a}}$ & $27.00 \pm 2.66^{\mathrm{b}}$ & $1.39 \pm 0.08^{\mathrm{ab}}$ \\
\hline $21 \%-40 \%$ & $2.39 \pm 0.31^{\mathrm{c}}$ & $0.12 \pm 0.01^{\mathrm{b}}$ & $30.25 \pm 0.64^{\mathrm{bc}}$ & $1.13 \pm 0.04^{\mathrm{bc}}$ \\
\hline $41 \%-60 \%$ & $1.39 \pm 0.26^{\mathrm{c}}$ & $0.10 \pm 0.01^{\mathrm{b}}$ & $31.94 \pm 0.77^{\mathrm{c}}$ & $1.01 \pm 0.06^{\mathrm{c}}$ \\
\hline
\end{tabular}

B. stellatifolium, Brabejum stellatifolium.

Means $\pm S E$ with the same letter are not significantly different, different letters denote means that are statistically different $(p<.05)$. significant and negatively correlated $\left(E: r^{2}=.34\right.$; Figure $\left.1 c\right)$ and varied over the four damage intervals $\left(F_{[1,49]}=7.735, p=.008\right.$; Table 1). Overall, the transpiration levels of leaves covered with black mould were low $\left(<2 \mathrm{mmol} \mathrm{m}^{-2} \mathrm{~s}^{-1}\right)$.

There were significant differences among leaf temperature values for leaf damage categories $\left(F_{[1,49]}=25.83, p<.001\right.$; Table 1$)$. The observed mould-induced decline in $A_{\max }$ may also be partially due to a temperature effect, as the abaxial surface temperature of black mould diseased leaves of the highest disease level was on average $4^{\circ} \mathrm{C}$ warmer than that of a mould-free leaf $\left(T_{\text {leaf }}: r^{2}=.52\right.$; Figure $\left.1 \mathrm{~d}\right)$.

While water content of wild almond leaves increased with increasing levels of black mould leaf coverage, the increase was not significant $\left(F_{[1,18}=1.69, p=.2\right.$; Figure $\left.\mathrm{S} 1\right)$. Leaf $\mathrm{N}$ content ranged from $0.2 \%$ to $1.6 \% \mathrm{DW}$ and leaf $\mathrm{P}$ content from $0.04 \%$ to $0.16 \%$ DW. There was a significant, negative correlation between nitrogen and levels of disease severity $\left(r^{2}=.56, p=.005\right)$. The relationship between $P$ and disease severity was very weak and insignificant $\left(r^{2}=.07, p=.25\right)$.

\subsection{Leaf spot (Phyllosticta owaniana) - photosynthesis and gas exchange relationships}

Phyllosticta owaniana leaf disease had a significant negative effect on photosynthetic rate of wild almond leaves $\left(F_{[1,57]}=82.32\right.$, $p<.001$; Table 2). As disease severity increased, $A_{\max }$ decreased significantly $\left(A_{\max }: r^{2}=.58\right.$; Figure 2a). $A_{\max }$ was reduced by approximately one half at $20 \%$ disease severity, and values approached zero for leaves with $>50 \%$ necrotic leaf area. Leaf stomatal conductance was strongly and negatively related to disease severity $\left(g_{s}: r^{2}=.66\right.$, Figure $\left.2 b\right)$, as indicated by significantly 


\begin{tabular}{lllll} 
Damage category & $A_{\max }$ & $g_{s}$ & $T_{\text {leaf }}$ & $E$ \\
\hline Control & $8.99 \pm 0.45^{\mathrm{a}}$ & $0.22 \pm 0.01^{\mathrm{a}}$ & $25.35 \pm 0.69^{\mathrm{a}}$ & $1.71 \pm 0.15^{\mathrm{a}}$ \\
\hline$>0 \%-20 \%$ & $7.69 \pm 0.48^{\mathrm{a}}$ & $0.13 \pm 0.01^{\mathrm{b}}$ & $22.08 \pm 3.50^{\mathrm{b}}$ & $1.57 \pm 0.09^{\mathrm{ab}}$ \\
\hline $21 \%-40 \%$ & $4.81 \pm 0.75^{\mathrm{b}}$ & $0.08 \pm 0.01^{\mathrm{b}}$ & $17.81 \pm 0.68^{\mathrm{c}}$ & $1.01 \pm 0.05^{\mathrm{bc}}$ \\
\hline $41 \%-60 \%$ & $3.18 \pm 0.58^{\mathrm{b}}$ & $0.08 \pm 0.03^{\mathrm{b}}$ & $13.53 \pm 0.90^{\mathrm{cd}}$ & $0.79 \pm 0.13^{\mathrm{bc}}$ \\
\hline $61 \%-80 \%$ & $2.91 \pm 0.31^{\mathrm{b}}$ & $0.09 \pm 0.07^{\mathrm{b}}$ & $11.30 \pm 0.23^{\mathrm{d}}$ & $0.41 \pm 0.15^{\mathrm{c}}$ \\
\hline
\end{tabular}

TABLE 2 The effects of leaf spot on photosynthetic rate $\left(A_{\max }\right)$, stomatal conductance $\left(g_{\mathrm{s}}\right)$, leaf temperature $\left(T_{\text {leaf }}\right)$ and leaf transpiration $(E)$ of B. stellatifolium leaves

B. stellatifolium, Brabejum stellatifolium.

Means $\pm S E$ in the same column with the same letter are not significantly different, different letters denote means that are statistically different $(p<.05)$.
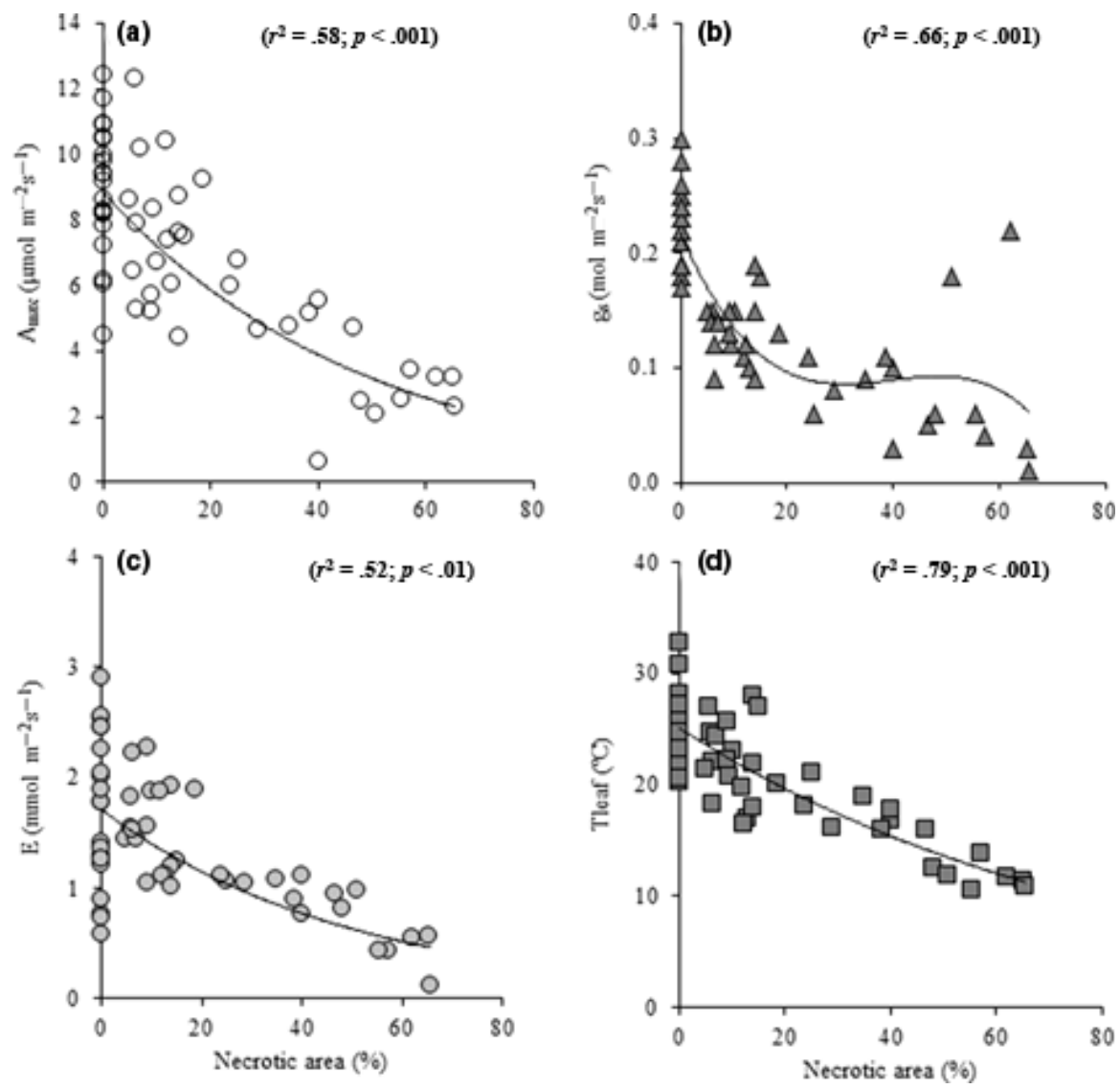

FIGURE 2 Effect of leaf area damaged by leaf spot on photosynthetic rate $\left(A_{\text {max }}\right.$ : a), net stomatal conductance $\left(g_{s}: b\right)$, and transpiration $(E: c)$ and leaf temperature ( $\left.T_{\text {leaf }}: d\right)$ of leaves in the crowns of wild almond trees infected by leaf spot. $r^{2}=$ Pearson's correlation coefficients. All the trends were nonlinear but polynomials provided the best fit

decreasing mean values $\left(F_{[1,57]}=22.1, p<.001\right.$; Table 2). Stomatal conductance stabilized at low levels for disease severity values between $21 \%$ and $80 \%$ of the lesioned leaf area (Figure $2 b$, Table 2). Leaf transpiration $\left(E: r^{2}=.52, F_{[1,57]}=14.08, p<.001\right.$; Table 2; Figure 2c) and leaf temperature ( $T_{\text {leaf }}: r^{2}=.79, F_{[1,}$ 57] $=29.64, p<.001$; Table 2; Figure $2 \mathrm{~d}$ ) were also negatively correlated with the necrotic area.

Contrary to the effect of black mould leaf coverage, there was a significant decrease in water content in leaves affected by leaf spot with increasing levels of fungal disease $\left(F_{[1,18]}=3.66, p=.02\right.$; Figure S2). Leaf spot severity only correlated significantly and negatively with $\mathrm{N}\left(r^{2}=.72, F_{[1,18]}=9.74, p<.001\right)$.

\section{3 | Weevil-folivory-photosynthesis and gas exchange relationship}

The effect of S. provinciale and S. quantillum mesophyll-feeding leaf weevils on the photosynthetic rate of wild almond leaves resulted in a significant nonlinear negative relationship $\left(r^{2}=.83, F_{[1,48]}=110.6\right.$, $p<.001$; Figure 3a). Photosynthetic rate was significantly reduced in leaves even at low levels of weevil folivory (Table 3). As infestation increased, an abrupt and significant decrease in photosynthetic rate occurred (Table 3).

Stomatal conductance of damaged leaves increased significantly with increasing damage severity $\left(g_{s}: r^{2}=.69, F_{[1,} 48\right]=11.12$, 
FIGURE 3 Photosynthetic rate $\left(A_{\max }\right.$; a), net stomatal conductance $\left(g_{s} ; b\right)$, and transpiration $(E ; c)$ and leaf temperature $\left(T_{\text {leaf }} ; d\right)$ of leaves in the crowns of wild almond trees damaged by folivorous insects (the weevils Setapion provinciale and Setapion quantillum). $r^{2}=$ Pearson's correlation coefficients. All the trends were nonlinear
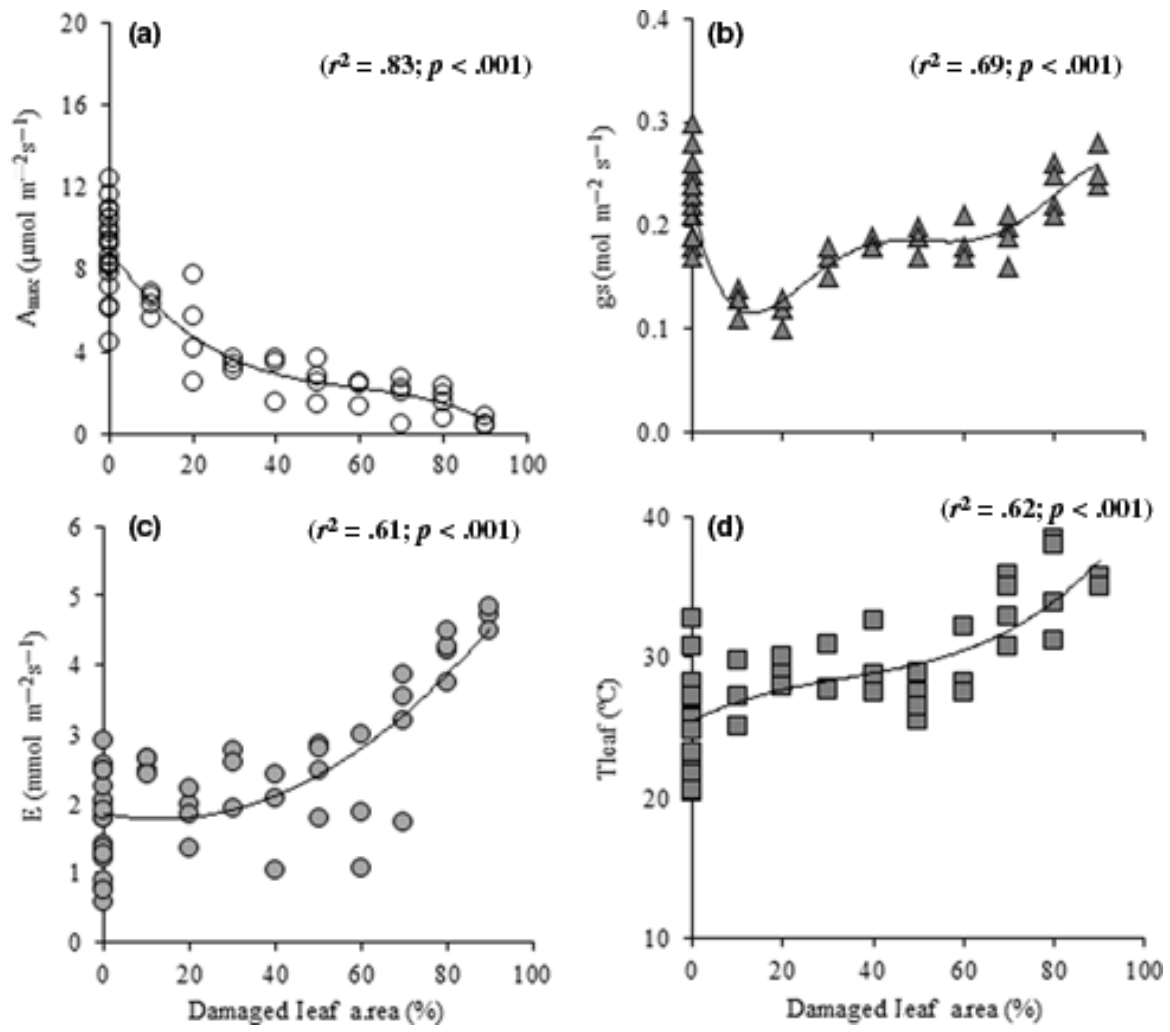

TABLE 3 Effects of folivorous insects (the weevils Setapion provinciale and Setapion quantillum) on photosynthetic rate $\left(A_{\text {max }}\right)$, stomatal conductance $\left(g_{s}\right)$, leaf temperature $\left(T_{\text {leaf }}\right)$ and leaf respiration $(E)$ of $B$. stellatifolium leaves

\begin{tabular}{lllll} 
Damage category & $A_{\max }$ & $g_{\mathrm{s}}$ & $T_{\text {leaf }}$ & $E$ \\
\hline Control & $8.99 \pm 0.45^{\mathrm{a}}$ & $0.22 \pm 0.01^{\mathrm{bc}}$ & $25.35 \pm 0.69^{\mathrm{a}}$ & $1.71 \pm 0.15^{\mathrm{a}}$ \\
\hline$>0 \%-20 \%$ & $5.69 \pm 0.59^{\mathrm{b}}$ & $0.12 \pm 0.004^{\mathrm{a}}$ & $27.61 \pm 0.66^{\mathrm{a}}$ & $2.20 \pm 0.16^{\mathrm{a}}$ \\
\hline $21 \%-40 \%$ & $3.11 \pm 0.33^{\mathrm{c}}$ & $0.18 \pm 0.01^{\mathrm{d}}$ & $27.97 \pm 0.86^{\mathrm{a}}$ & $2.13 \pm 0.25^{\mathrm{a}}$ \\
\hline $41 \%-60 \%$ & $2.38 \pm 0.31^{\mathrm{c}}$ & $0.19 \pm 0.01^{\mathrm{cd}}$ & $29.15 \pm 0.81^{\mathrm{a}}$ & $2.26 \pm 0.26^{\mathrm{a}}$ \\
\hline $61 \%-80 \%$ & $1.73 \pm 0.28^{\mathrm{c}}$ & $0.22 \pm 0.01^{\mathrm{bcd}}$ & $34.45 \pm 1.02^{\mathrm{b}}$ & $3.63 \pm 0.31^{\mathrm{b}}$ \\
\hline $81 \%-100 \%$ & $0.57 \pm 0.16^{\mathrm{c}}$ & $0.26 \pm 0.01^{\mathrm{b}}$ & $35.33 \pm 0.23^{\mathrm{b}}$ & $4.68 \pm 0.11^{\mathrm{b}}$ \\
\hline
\end{tabular}

Means $\pm S E$ in each column with the same letter are not significantly different, different letters denote means that are statistically different $(p<.05)$. $p<.001$; Figure 3b). There was a significant effect of folivory severity on leaves with both transpiration rates $\left(E: r^{2}=.61, F_{[1}\right.$, ${ }_{48}=16.10, p<.001$; Table 3; Figure 3c) and leaf temperature $\left(T_{\text {leaf: }}\right.$ : $r^{2}=.62, F_{[1,48]}=25.27, p<.001$; Table 3; Figure 3d) being higher in damaged leaves than they were in healthy leaves. Both transpiration and leaf temperature showed a significant spike at the highest damage classes compared to the less severe damage classes (Table 3).

Water content of wild almond leaves showed no change with increasing levels of folivory $\left(F_{[1,18]}=1.27, p=.3\right)$ when compared to their respective controls. No relationship was observed between weevil damage and leaf $\mathrm{N}$ content $\left(r^{2}=.09, F_{[1,18]}=1.01, p=.18\right)$ and $P\left(r^{2}=.05, F_{[1,18]}=1.36, p=.36\right)$. All the trends were nonlinear.

\section{4 | DISCUSSION}

\section{1 | Phytopathogens}

In this study, phytopathogens caused steep reductions in the photosynthetic rate of leaf tissue, which agrees with results of previous studies (e.g., Oliveira, Sousa, Alves, Nogueira, \& Santos, 2012). Here, when disease severity reached $40 \%$ of leaf area, photosynthetic rate was reduced threefold. This implies that a minor increase in infections of phytopathogens has a dramatic, negative impact on plant health as measured by photosynthetic rate. The reduction in photosynthetic rate of infected leaves has been shown to depend on stomatal functioning (Aldea et al., 2005; Lopes \& Berger, 2001). Previous studies suggest that phytopathogens can either reduce (Prats, 
Carver, Gay, \& Mur, 2007) or increase (Allègre et al., 2007; Lopes \& Berger, 2001; Oerke, Steiner, Dehne, \& Lindenthal, 2006) stomatal conductance. In our study, stomatal conductance of wild almond leaves decreased sharply with increase in fungal disease severity. The heavy coverage of black mould on the abaxial leaf surface has been shown to cover the stomata (see Filho \& Paiva, 2006; Santos, Alves-Silva, et al., 2013; Santos, Santos, et al., 2013). The main result of this interference is that the normal gas exchange processes of diseased parts of the leaves are severely affected with negative consequences for production (Santos, Alves-Silva, et al., 2013; Santos, Santos, et al., 2013). This indicates that B. stellatifolium is, when under heavy black mould coverage and severe damage by leaf spot, severely stressed as its normal metabolism is affected.

In wild almond leaves, the decrease in stomatal conductance mirrored a decrease in transpiration, thereby lowering the internal concentration of water vapour and hence affecting photosynthetic rate. No other mechanisms could be inferred from the measurements taken, although the likelihood of other mechanisms cannot be excluded. Grimmer, Foulkes, and Paveley (2012) in their review sug gested that the decrease in transpiration may be related to the method in which phytopathogens infect leaves. For example, fungi causing necrotic lesions like $P$. owaniana produce spore-bearing structures that can use the stomatal pores as entry route or erupt through the epidermis, breaking open the cuticle (Grimmer et al., 2012). It has also been shown that phytopathogens associated with a reduction in transpiration are associated with hypertrophy of chlorenchyma, reduction in air spaces, or obstruction of conductive tissue and stomata (Siddiqui \& Akhtar, 2007).

Apart from the above-mentioned variables, the observed disease-induced decline in photosynthetic rate may also be partially due to a temperature effect (Archontoulis, Yin, Vos, Danalatos, \& Struik, 2012; Hüve et al., 2012). High temperature exacerbates reductions in photosynthetic rate (Hüve et al., 2012; Olufemi et al., 2002). However, this may be applicable only to black mould damage. Olufemi et al. (2002) showed that an increase of about $4^{\circ} \mathrm{C}$ is enough to contribute to suppression of photosynthetic rate of Mangifera indica (L.) leaves. As leaf temperatures of wild almond covered by black mould increased by about $4^{\circ} \mathrm{C}$ in diseased leaves compared to the nondiseased controls, it is likely that leaf temperature may partially be responsible for the decline in photosynthetic rate. However, this is not the case with leaf spot, where temperature declined with a decline in photosynthetic rate. This implies that although the two fungi have similar major impacts on photosynthesis, the mechanisms behind these impacts differ. The heating effect by black mould coverage may be partially due to the natural absorption of radiant energy by dark objects as well as because the mould acts as a barrier to air movement with a loss of control over transpiration-induced cooling. Changes in membrane semi-permeability brought about by phytopathogens that cause physical lesions on the leaf surface like leaf spot often result in decreases in leaf temperature due to alteration of leaf water status (e.g., Oerke et al., 2006).

This study also showed that leaf spot disease, but not black mould, may affect nutrient absorption and/or translocation, as leaf water content decreased significantly with increase in disease severity. It is possible that the observed decreases in water content under increased leaf spot reduce leaf tolerance to desiccation induced by disease damage. The lack of a relationship between black mould and leaf water content was not expected as accumulation of a biotrophic fungal pathogen mat has potential to reduce penetration of sunlight and stomatal opening, thus suppressing water loss (see Filho \& Paiva, 2006).

As plants use defences such as increasing the level of leaf tannins and lignins to mitigate biotic stressors (War et al., 2012), a significant decrease in the levels of $\mathrm{N}$ as observed here could possibly represent a reduction in plant defences against phytopathogens. Plants may translocate $\mathrm{N}$ to leaves that are less affected or to healthy leaves, such as was found by Munns (2002). Either one or a combination of these responses would result in a decline in photosynthetic rate as nitrogen is essential to photosynthesis. The lack of a response of leaf $P$ content to black mould infections and leaf $P$ content for leaf spot suggest that factors other than $\mathrm{P}$ and leaf water content have an effect on the amount of leaf material diseased or that they are not related to severity of phytopathogens. This warrants further research.

\section{2 | Insect folivory}

Insect folivory has been shown to either increase or decrease (e.g., see Heng-Moss et al., 2006; Zangerl et al., 2002) photosynthetic rate. In this study, damage from the mesophyll-feeding leaf weevils S. provinciale and S. quantillum caused large reductions in photosynthetic rate. The presence of even a few scars representing $<0.5 \%$ of leaf area was enough to significantly reduce photosynthetic rate, which implies that at a tree level, even light insect damage can reduce production. This also means weevil damage can have a potentially large impact on the health of B. stellatifolium. The decrease in photosynthetic rate due to folivory is usually attributed to a decrease in stomatal conductance to compensate for nonstomatal water loss around folivory damage (Aldea et al., 2005). Contrary to this, stomatal conductance of damaged leaves increased with increasing damage severity in this study. This is, however, consistent with results of previous studies investigating effects of chewing insects on plant physiology (Aldea et al., 2005; Marlin, Hill, Ripley, Strauss, \& Byrne, 2013; Neves, Oliveira, \& Parra, 2006). The increased stomatal conductance is likely because the weevils considered in this study create numerous very small openings in the cuticle, which explains the increase in stomatal conductance, and, in turn, the observed increase in transpiration. Increased evaporative water loss implies leaf cooling, which was not found in Setapiondamaged leaves of B. stellatifolium. Instead, leaf temperature increased, which is consistent with Peterson, Higley, Haile, and Barrigossi (1998). This increase in leaf temperature suggests some dehydration of the tissue along the edges of the chew damage, an observation previously reported by Peterson, Shannon, and Lenssen (2004), which could result in a loss of temperature regulation through transpirational cooling. 
Although increases in folivory severity have been related to increases in leaf water content in other studies (Münzbergová \& Skuhrovec, 2013; Ricklefs, 2008), it was not the case for this study. Factors other than water relations may be involved in the reaction of $B$. stellatifolium to folivores. Sufficient leaf $\mathrm{P}$ and $\mathrm{N}$ are well-acknowledged fundamental requirements for proper cellular functioning and growth of consumers (Elser et al., 2000; Richardson, Press, Parsons, \& Hartely, 2002; Ricklefs, 2008). Leaf $\mathrm{N}$ content ranged from $0.2 \%$ to $1.6 \%$ of DW while leaf $\mathrm{P}$ content ranged from $0.04 \%$ to $0.16 \% \mathrm{DW}$; these levels are within the range found with plants that grow under natural conditions (Center, Dray, Jubinsky, \& Grodowitz, 1999). Huberty and Denno (2006) reported that both leaf $N$ and $P$ contents increased with increasing folivores damage. Relative to that study, our expectation was that a significant correlation should exist between $\mathrm{N}$ and folivory severity, however, this was not found.

It was previously noted by Maoela et al. (2016) that native trees in restored sites (cleared of mostly woody invasive alien plants) continue to be damaged by folivorous insects and phytopathogens resulting in damage levels in excess of that seen at invaded sites. And results from the current study further showed that different diseases have different effects on leaf photosynthetic capacity and water relations, and likely affect leaf physiology through different mechanisms, although the ultimate impact on physiology may be similar. A slight increase in severity of folivory and phytopathogens can have severe effects on tree metabolic functioning (e.g., decreased photosynthetic rate). While the mechanisms are unclear, the resultant compromised physiology of B. stellatifolium may partially explain the slow recovery of plant cover of this species in restored sites. This information enough to benefit river managers and policy makers when (re)defining and planning restoration strategies of degraded riparian habitats in South Africa. Specifically, plantand leaf-level traits can indicate how to manipulate properties of plant and arthropod communities to optimize restoration of invaded ecosystems.

\section{ACKNOWLEDGEMENTS}

We are grateful to Oliver Kambaj for field assistance, while the manuscript benefitted greatly from inputs by Samuel Adu-Acheampong. We thank CapeNature for access to field sites (Permit Number: AAA008-00027-0028). Funds for this study were provided by the DST/NRF Centre of Excellence in Tree Health Biotechnology. The funds were administered by Stellenbosch University, which provided research facilities.

\section{CONFLICT OF INTEREST}

The authors declare that they have no conflict of interest.

\section{ORCID}

Malebajoa A. Maoela iD http://orcid.org/0000-0001-5886-7991

\section{REFERENCES}

Agrawal, A. A., Karban, R., \& Colfer, R. G. (2000). How leaf domatia and induced plant resistance affect herbivores, natural enemies and plant performance. Oikos, 89, 70-80.

Aldea, M., Hamilton, J. G., Resti, J. P., Zangerl, A. R., Berenbaum, M. R., \& Delucia, E. H. (2005). Indirect effects of insect herbivory on leaf gas exchange in soybean. Plant, Cell and Environment, 28, 402-411.

Aldea, M., Hamilton, J. G., Resti, J. P., Zangerl, A. R., Berenbaum, M. R. Frank, T. D., \& Delucia, E. H. (2006). Comparison of photosynthetic damage from arthropod herbivory and pathogen infection in understory hardwood saplings. Oecologia, 149, 221-232.

Allègre, M., Daire, X., Héloir, M.-C., Trouvelot, S., Mercier, L., Adrian, M., \& Puzrgin, A. (2007). Stomatal deregulation in Plasmopara viticola infected grapevine leaves. New Phytologist, 173, 832-840.

Archontoulis, S. V., Yin, X., Vos, J., Danalatos, N. G., \& Struik, P. C. (2012). Leaf photosynthesis and respiration of three bioenergy crops in relation to temperature and leaf nitrogen: How conserved are biochemical model parameters among crop species? Journal of Experimental Botany, 63, 895-911.

Arzanlou, M., Groenewald, J. Z., Gams, W., Braun, U., Shin, H. D., \& Crous, P. W. (2007). Phylogenetic and morphotaxonomic revision of Ramichloridium and allied genera. Studies in Mycology, 58, 57-93.

Awmack, C. S., \& Leather, S. R. (2002). Host plant quality and fecundity in herbivorous insects. Annual Review of Entomology, 47, 817-844.

Ayres, M. P., Wilkens, R. T., Ruel, J. J., Lombardero, M. J., \& Vallery, E. (2000). Nitrogen budgets of phloem-feeding bark beetles with and without symbiotic fungi. Ecology, 81, 2198-2210.

Bancal, M. O., Robert, C., \& Ney, B. (2007). Modelling wheat growth and yield losses from late epidemics of foliar diseases using loss of green leaf area per layer and pre-anthesis reserves. Annals of Botany, 100, 777-789.

Bechtold, U., Karpinski, S., \& Mullineaux, P. M. (2005). The influence of the light environment and photosynthesis on oxidative signalling responses in plant-biotrophic pathogen interactions. Plant, Cell and Environment, 28, 1046-1055.

Bentz, J., \& Townsend, A. M. (2001). Leaf element content and utilization of maple and elm as hosts by the potato leafhopper (Homoptera: Cicadellidae). Environmental Entomology, 30, 533-539.

Bown, A. W., Hall, D. E., \& Macgregor, K. B. (2002). Insect footsteps on leaves stimulate the accumulation of 4-aminobutyrate and can be visualized through increased chlorophyll fluorescence and superoxide production. Plant Physiology, 129, 1430-1434.

Bradford, J. B., Hicke, J. A., \& Lauenroth, W. K. (2005). The relative importance of light-use efficiency modifications from environmental conditions and cultivation for estimation of large-scale net primary productivity. Remote Sensing of Environment, 96, 246-255.

Buys, M. R., van der Walt, J. J. A., \& Boucher, C. (1991). A provisional analysis of the flora of Stellenbosch. South African Journal of Botany, 57, 264-290

Carmona, D., Lajeunesse, M. J., \& Johnson, M. T. J. (2011). Plant traits that predict resistance to herbivores. Functional Ecology, 25, 358367.

Carvalho, M. R., Wilf, P., Barrios, H., Windsor, D. M., Currano, E. D., Labandeira, C. C., \& Jaramillo, C. A. (2014). Insect leaf-chewing damage tracks herbivore richness in modern and ancient forests. PLoS One, 9, e94950.

Center, T. D., Dray, F. A., Jubinsky, G. P., \& Grodowitz, M. J. (1999). Biological control of water hyacinth under conditions of maintenance management: Can herbicides and insects be integrated? Environmental Management, 23, 241-256.

Crous, C. J., Jacobs, S. M., \& Esler, K. J. (2011). Drought-tolerance of an invasive alien tree, Acacia mearnsii and two native competitors in fynbos riparian ecotones. Biological Invasions, 3, 619-631. 
Dicke, M., \& Hilker, M. (2003). Induced plant defences: From molecular biology to evolutionary ecology. Basic and Applied Ecology, 4, 3-14.

Djassinra, T., Elhartiti, A., Mammad, Z., \& Ounine, K. (2015). Behavior of Xanthomonas fragariae in an inorganic medium enriched with $\mathrm{N}, \mathrm{P}$, or $\mathrm{K}$. International Journal of Innovation and Scientific Research, 17, 99-113.

Eichhorn, M. P., Nilus, R., Compton, S. G., Hartley, S. E., \& Burslem, D. (2010). Herbivory of tropical rain forest tree seedlings correlates with future mortality. Ecology, 91, 1092-1101.

Elser, J. J., Fagan, W. F., Denno, R. F., Dobberfuhl, D. R., Folarin, A., Huberty, A., ... Sterner, R. W. (2000). Nutritional constraints in terrestrial and freshwater food webs. Nature, 408, 578-580.

Filho, J. P. L., \& Paiva, E. A. S. (2006). The effect of sooty mold on photosynthesis and mesophyll structure of mahogany (Swietenia macrophylla King., Meliaceae). Bragantia, 65, 11-17.

Franzluebbers, A. J., \& Hill, N. S. (2005). Soil carbon, nitrogen, and ergot alkaloids with short- and long-term exposure to endophyte-infected and endophyte-free tall fescue. Journal of the Soil Science Society of America, 69, 404412.

García-Guzmán, G., \& Dirzo, R. (2001). Patterns of leaf-pathogen infection in the understory of a Mexican rain forest: Incidence, spatiotemporal variation, and mechanisms of infection. American Journal of Botany, 88, 634-645.

García-Guzmán, G., \& Dirzo, R. (2004). Incidence of leaf pathogens in the canopy of a Mexican tropical wet forest. Plant Ecology, 172, 31-50.

Grimmer, M. K., Foulkes, M. J., \& Paveley, N. D. (2012). Foliar pathogenesis and plant water relations: A review. Journal of Experimental Botany, 63, 4321-4331.

Heng-Moss, T., Macedo, T., Franzen, L., Baxendale, F., Higley, L., \& Sarath, G. (2006). Physiological responses of resistant and susceptible buffalo grasses to Blissus occiduus (Hemiptera: Blissidae) feeding. Journal of Economic Entomology, 99, 222-228.

Hoot, S. B., \& Douglas, A. W. (1998). Phylogeny of the Proteaceae based on atpB and atpB-rbcL intergenic spacer region sequences. Australian Systematic Botany, 11, 301-320.

Huberty, A. F., \& Denno, R. F. (2006). Consequences of nitrogen and phosphorus limitation for the performance of two plant hoppers with divergent life-history strategies. Oecologia, 149, 444-455.

Hüve, K., Bichele, I., Ivanova, H., Keerberg, O., Pärnik, T., Rasulov, B., ... Niinemets, Ü. (2012). Temperature responses of dark respiration in relation to leaf sugar concentration. Physiologia Plantarum, 144, 320334.

Jouraeva, V. A., Johnson, D. L., Hassett, J. P., Nowak, D. J., Shipunova, N. A., \& Barbarossa, D. (2006). Role of sooty mold fungi in accumulation of fine-particle-associated PAHs and metals on deciduous leaves. Environmental Research, 102, 272-282.

Kessler, A., \& Baldwin, I. T. (2002). Plant responses to insect herbivory: The emerging molecular analysis. Annual Review of Plant Biology, 53, 299-328.

King, E. G., \& Caylor, K. K. (2010). Herbivores and mutualistic ants interact to modify tree photosynthesis. New Phytologist, 187, 17-21.

Larkin, B. G., Hunt, L. S., \& Ramsey, P. W. (2012). Foliar nutrients shape fungal endophyte communities in Western white pine (Pinus monticola) with implications for white-tailed deer herbivory. Fungal Ecology, $5,252-260$

León, J., Rojo, E., \& Sanchez-Serrano, J. J. (2001). Wound signalling in plants. Journal of Experimental Botany, 52, 1-9.

Lopes, D. B., \& Berger, R. D. (2001). The effects of rust and anthracnose on the photosynthetic competence of diseased bean leaves. Phytopathology, 91, 212-220.

Manter, D. K., \& Kavanagh, K. L. (2003). Stomatal regulation in Douglas fir following a fungal-mediated chronic reduction in leaf area. Trees Structure and Function, 17, 485-491.

Maoela, M. A., Jacobs, S. M., Roets, F., \& Esler, K. J. (2016). Invasion, alien control and restoration: Legacy effects linked to folivorous insects and phylopathogenic fungi. Austral Ecology, 41(8), 906-917.
Marlin, D., Hill, M. P., Ripley, B. S., Strauss, A. J., \& Byrne, M. J. (2013). The effect of herbivory by the mite Orthogalumna terebrantis on the growth and photosynthetic performance of water hyacinth (Eichhornia crassipes). Aquatic Botany, 104, 60-69.

Martínez-Minaya, J., Conesa, D., Lopez-Quilez, A., \& Vicent, A. (2015). Climatic distribuition of citrus black spot caused by Phyllosticta citricarpa. A historical analysis of disease spread in South Africa. European Journal of Plant Pathology, 143, 69-83.

Mithöfer, A., \& Boland, W. (2012). Plant defense against herbivores: Chemical aspects. Annual Review of Plant Biology, 63, 431-450.

Munns, R. (2002). Comparative physiology of salt and water stress. Plant, Cell and Environment, 25, 239-250.

Münzbergová, Z., \& Skuhrovec, J. (2013). Effect of habitat conditions and plant traits on leaf damage in the Carduoideae subfamily. PLoS One, 8, e64639.

Nabity, P. D., Zavala, J. A., \& Delucia, E. H. (2009). Indirect suppression of photosynthesis on individual leaves by arthropod herbivory. Annals of Botany, 103, 655-663.

Neves, A. D., Oliveira, R. F., \& Parra, J. R. P. (2006). A new concept for insect damage evaluation based on plant physiological variables. Anais da Academia Brasileira de Ciências, 78, 821-835.

Oerke, E.-C., Steiner, U., Dehne, H.-W., \& Lindenthal, M. (2006). Thermal imaging of cucumber leaves affected by downy mildew and environmental conditions. Journal of Experimental Botany, 57, 2121-2132.

Oliveira, H., Sousa, A., Alves, A., Nogueira, A. J. A., \& Santos, C. (2012). Inoculation with Ophiostoma novo-ulmi subsp. americana affects photosynthesis, nutrition and oxidative stress in in-vitro Ulmus minor plants. Environmental and Experimental Botany, 77, 146-155.

Olufemi, O. R. P., Georgina, M., Sunday, O. S. A., Oyeboade, S. A., \& Taiwo, A. A. (2002). Effect of mango mealybug and sooty mould attack on mango and the impact of the released Gyranusoidea tebygi Noyes on yield. Fruits, 57, 105-113.

Pellegrini, E., Campanella, A., Paolocci, M., Trivellini, A., Gennai, C., Muganu, M., ... Lorenzini, G. (2015). Functional leaf traits and diurnal dynamics of photosynthetic parameters predict the behavior of grapevine varieties towards ozone. PLoS One, 10, e0135056.

Peterson, R. K. D., Higley, L. G., Haile, F. J., \& Barrigossi, J. A. F. (1998). Mexican bean beetle (Coleoptera: Coccinellidae) injury affects photosynthesis of Glycine max and Phaseolus vulgaris. Environmental Entomology, 27, 373-381.

Peterson, R. K. D., Shannon, C. L., \& Lenssen, A. W. (2004). Photosynthetic responses of legume species to leaf-mass consumption injury. Environmental Entomology, 33, 450-456.

Prats, E., Carver, T. L. W., Gay, A. P., \& Mur, L. A. J. (2007). Interactionspecific stomatal responses to pathogenic challenge. Plant Signaling and Behavior, 2, 275-277.

Procheş, S. (2007). Wild almond ark: Brabejum stellatifolium and its unique load of passengers. Veld and Flora, 2, 86-88.

Richardson, S. J., Press, M. C., Parsons, A. N., \& Hartely, S. E. (2002). How do nutrients and warming impact on plant communities and their insect herbivores? A 9-year study from a sub-Arctic heath. Ecology, 90, 544-556.

Ricklefs, R. (2008). Foliage chemistry and the distribution of Lepidoptera larvae on broad-leaved trees in southern Ontario. Oecologia, 157, 53 67.

Robert, C., Bancal, M. O., \& Lannou, C. (2002). Wheat leaf rust uredospore production and carbon and nitrogen export in relation to lesion size and density. Phytopathology, 92, 76-768.

Robert, C., Bancal, M. O., Ney, B., \& Lannou, C. (2005). Wheat leaf photosynthesis loss due to leaf rust, with respect to lesion development and leaf nitrogen status. New Phytologist, 165, 227-241.

Sack, L., \& Holbrook, N. M. (2006). Leaf hydraulics. Annual Review of Plant Biology, 57, 361-381.

Sáez-Plaza, P., Michałowski, T., Navas, M. J., \& Asuero, A. G. (2013). An overview of the Kjeldahl method of nitrogen determination. Part II. 
Sample preparation, working scale, instrumental finish, and quality control. Critical Reviews in Analytical Chemistry, 43, 224-272.

Santos, J. C., Alves-Silva, E., Cornelissen, T. G., \& Fernandes, G. W. (2013). The effect of fluctuating asymmetry and leaf nutrients on gall abundance and survivorship. Basic and Applied Ecology, 14, 489-495.

Santos, S. A. P., Santos, C., Silva, S., Pinto, G., Torres, L. M., \& Nogueira, A. J. A. (2013). The effect of sooty mold on fluorescence and gas exchange properties of olive tree. Turkish Journal of Biology, 37, 620-628.

Schowalter, T.D. (2012) Insect herbivore effects on forest ecosystem services. Journal of Sustainable Forestry 31, 518-536.

Siddiqui, Z. A., \& Akhtar, M. S. (2007). Effects of AM fungi and organic fertilizers on the reproduction of the nematode Meloidogyne incognita and on the growth and water loss of tomato. Biology and Fertility of Soils, 43, 603-609.

Sinclair, R. J., \& Hughes, L. (2010). Leaf miners: The hidden herbivores. Austral Ecology, 35, 300-313.

Small, I. M., Flett, B. C., Marasas, W. F. O., McLeod, A., \& Viljoen, A. (2012). Use of resistance elicitors to reduce Fusarium ear rot and fumonisin accumulation in maize. Crop Protection, 41, 10-16.

Snoeijers, S., Pérez-Garcia, A., Joosten, M., \& Wit, P. D. (2000). The effect of nitrogen on disease development and gene expression in bacterial and fungal plant pathogens. European Journal of Plant Pathology, 106, 493-506.

Stone, J. K., Polishook, J. D., \& White, J. F. (2004). Endophytic fungi. In G. M. Mueller, G. F. Bills, \& M. S. Foster (Eds.), Biodiversity of fungi (pp. 241-270). Amsterdam: Elsevier.

Swart, L., Crous, P. W., Denman, S., \& Palm, M. E. (1998). Fungi occurring on proteaceae. I. South African Journal of Botany, 64, 137-145.

Sweeney, D. W., Granade, G. V., Eversmeyer, M. G., \& Whitney, D. A. (2000). Phosphorus, potassium, chloride, and fungicide effects on wheat yield and leaf rust severity. Journal of Plant Nutrition, 23, 1267-1281.

Swift, C., Jacobs, S., \& Esler, K. J. (2008). Drought induced xylem embolism in four riparian trees from the Western Cape Province: Insights and implications for planning and evaluation of restoration. South African Journal of Botany, 74, 508-516.

Tatagiba, S. D., Damatta, F. M., \& Rodrigues, F. A. (2015). Leaf gas exchange and chlorophyll a fluorescence imaging of rice leaves infected with Monographella albescens. Journal of Phytopathology, 105, 180-188.

Tatagiba, S. D., Rodrigues, F. A., Filippi, M. C. C., Silva, G. B., \& Silva, L. C. (2014). Physiological responses of rice plants supplied with silicon to Monographella albescens infection. Journal of Phytopathology, 162, 596-606.

Thomson, V. P., Cunningham, S. A., Ball, M. C., \& Nicotra, A. B. (2003). Compensation for herbivory by Cucumis sativus through increased photosynthetic capacity and efficiency. Oecologia, 134, 167-175.

Velikova, V., Salerno, G., Frati, F., Peri, E., Conti, E., Colazza, S., \& Loreto, F. (2010). Influence of feeding and oviposition by phytophagous pentatomids on photosynthesis of herbaceous plants. Journal of Chemical Ecology, 36, 629-641.

Walters, D. R., \& Bingham, I. J. (2007). Influence of nutrition on disease development caused by fungal pathogens: Implications for plant disease control. Annals of Applied Biology, 151, 307-324.

War, A. R., Paulraj, M. G., Ahmad, T., Buhroo, A. A., Hussain, B., Ignacimuthu, S., \& Sharma, H. C. (2012). Mechanisms of plant defense against insect herbivores. Plant Signaling and Behaviour, 7, 13061320.

Werger, M. J. A., Kruger, F. J., \& Taylor, H. C. (1972). A phytosociological study of the Cape fynbos and other vegetation at Jonkershoek, Stellenbosch. Bothalia, 10, 599-614.

Yang, C., Guo, R., Jie, F., Nettleton, D., Peng, J., Carr, T., ... Whitham, S. A. (2007). Spatial analysis of Arabidopsis thaliana gene expression in response to Turnip mosaic virus infection. Molecular Plant-Microbe Interactions, 20, 358-370.

Zangerl, A. R., Hamilton, J. G., Miller, T. J., Crofts, A. R., Oxborough, K., Berenbaum, M. R., \& Delucia, E. H. (2002). Impact of folivory on photosynthesis is greater than the sum of its holes. Proceedings of the National Academy of Sciences of the United States of America, 99, 1088-1109.

Zvereva, E. L., Lanta, V., \& Kozlov, M. V. (2010). Effects of sap-feeding insect herbivores on growth and reproduction of woody plants: A meta-analysis of experimental studies. Oecologia, 163, 949-960.

\section{SUPPORTING INFORMATION}

Additional Supporting Information may be found online in the supporting information tab for this article.

How to cite this article: Maoela MA, Esler KJ, Roets F, Jacobs SM. Physiological responses to folivory and phytopathogens in a riparian tree, Brabejum stellatifolium, native to the fynbos biome of South Africa. Afr J Ecol. 2018;56:477-487. https://doi.org/10.1111/aje.12481 